\title{
CONSTITUTION AND COURT AS SYMBOLS
}

\author{
MAX LERNER $\dagger$
}

We live by symbols.

-Mr. Justice Holmes ${ }^{1}$

\section{Symbols Possess Men}

Lrke children and neurotics man as a political animal lives in a world riddled with bugbears and tabus - a dream-world of symbols in which the shadows loom far larger than the realities they represent." Political thinkers as diverse as the English idealists and the classical Marxians ${ }^{3}$ have incurred a common fallacy: they have taken their own sense of the logical relation of things and read it into the way men behave. Actually men behave in their political lives with a disheartening illogicality. ${ }^{4}$ They live in a jungle of fear, filled with phantoms of what they

$\dagger$ Editor, The Nation.

This is the first chapter of a book to be published in the fall by the Viking Press, under the title The Divine Right of Judges: A Study in the American Supreme Court. It will be readily apparent in this essay how much I owe to other writers: to Corwin, The Constitution as Instrument and as Symbol (1936) 30 AM. Pox. Scr. Rev. 1071 (Harvard Tercentenary address); to Schechter, The Early History of the Tradition of the Constitution (1915) 9 Am. PoL. Sct. Rev. 707; to Hamilton, Constitutionalism (1931) 4 Encyc. Soc. Sciences 255; to Arnold, The Symbols of Governaneit (1935); to Frank, Law and the Modern Mind (1930). This essay is in a sense a gloss on their combined text. I have, incidentally, used rather freely sentences from my series of articles, The Riddle of the Supreme Court (1936) 142 Natron 121, 213, 273, 379.

1. Collected Legal Papers (1920) 270.

2. Sigmund Freud's profound although erratic insights into the human mind have not yet been measurably appropriated by social theory. His own attempts to apply his method to the problems of culture, including his Civilization and ITs Discontents (Riviere trans. 1930), are readable but rudimentary. Modern readers will still find Bagenot, Physics and Politics (1873) and Wallas, Human Natuke in Politics (3d ed. 1914) suggestive; while the first writer was a conservative and the second a Fabian, both were radical in the sense that they refused to believe in the fiction that man is a rational animal. The most valuable dislocations of our political thinking have come from the classical anthropologists, such as Tylor and Frazer-dislocations which I have tried to describe in an (unsigned) survey of anthropological trends, Introduction (1930) 1 ENCXC. Soc. SCIENCES 199-203. We are still awaiting a commentary on Aristotle's "Man is a political animal," written by someone who has mastered the insights of modern psychology and anthropology.

3. For the English idealists, see Laski, The State in Theory and Practice (1935) c. 1 ("The Philosophic Conception of the State"). The rationalism of the classical Marxians seem to me their greatest weakness; nor have the contemporary Marxians yet succeeded in effecting a fusion between their profoundly valid theory of history and a usable psychology.

4. Illogical behavior and logical rationalization of that behavior go hand in hand. This is the core of truth in PARETo, The MIND AND Society (Livingston and Bongiono trans. 1935). For the American reader Thurman Arnold's book, Symbols of Govern- 
have heard and imagined and been told. Their world is the world of a child's nightnares - dark and brooding, crowded with dreads and anxieties, with the distortions of real objects, with the cruellest nonsequiturs and anti-climaxes.

That is why men always find themselves forced to seek some symbol of divine right. Talk to the men on the street, the men in the mines and factories and steel-mills and real-estate offices and filling stations, dig into their minds and even below the threshold of their consciousness, and you will in the main find that Constitution and Supreme Court are symbols of an ancient sureness and a comforting stability. If you watch the black-robed justices as they come filing in, if you listen to then read their opinions, you will be strong not to succumb to a sense of the Court's timelessness. Americans have been told that they are a people without a tradition, without a culture." And it does in truth seem surprising that the restless, unstable energies of the American people should have created anything that seems as deep-rooted and as timeless as the Supreme Court. Even today, in its new and imposing building, ${ }^{6}$ the Court still wears the ancient garments of divine right. The building has changed since the days of Joln Jay and John Marshall; the fashionables, the men of power, the plain men and women who come to visit the Court have changed; there is even that strange and modern creature, a "press contact man," to explain to correspondents the mysteries of a writ of cerliorari and a dissenting opinion. But despite these concessions to the spirit of the times, the Court maintains its tough historical fiber. It has the knack that it seems to have borrowed from the English institutions - that of managing to survive somehow with its eye peeled continually on the past. It has, to be sure, walked along the evolutionary path, but only as Orpheus once walked along the pathway out of Hell - with its head turned backward.

What accounts for the extraordinary toughness and viability of the Court? Why has it emerged from its mortal combats with Presidents, presidential candidates and political reformers from Jefferson to Roosevelt II relatively unscathed? The defenders of the Court answer that

MENT (1935), is much more to the point than Pareto. One of the most suggestive and readable explorations of irrationality and rationalization in the western world is still Robinson, The Mind in the Making (1921).

5. Especially by the English commentators. This has been the principal element in what James Russell Lowell called "a certain condescension" in them. It is notable that no Englishman, with the recent exceptions of Harold Laski and D. W. Brogan, has concerned himself much with American judicial review. Bryce was not particularly acute about it. And even Dicey made the mistake of seeing judicial review as an inherent part of the federal structure.

6. For an amusing description of the new building and the Washington foll:lore that has already clustered around it, see Pearson and Alzen, Tae Nine Old Mesi (1936) c. 1 ("The Taj Míahal"). 
its survival indicates the hollowness of the attacks on it. ${ }^{7}$ The assumption seems to be that what is involved is a mediaeval ordeal by fire, proving innocence. But the successive crises of the judicial power can no more be exorcised by this sort of mumbo-jumbo than can the crises of the economic system. They cannot be explained away merely as "the same old story." The attacks on the Court's power have been real enough and dangerous enough. Its survival thus far shows that it has deep historical and psychological roots in American life: it has a clear relation to the development of the power of business enterprise; it has a strong symbolic hold over the American mind.

Most clearly and simply I should put it as follows: the nature and extent of the Supreme Court's power are best understood by seeing it as our basic instrument of sovereignty - an integral part of the American capitalist economic order. But the support of the judicial power lies largely in the psychological realm; its roots are in the minds of the people. Historically the judicial power must be seen as the instrument of the few; psychologically it is the symbol of the many. "We live by symbols," wrote Mr. Justice Holmes. It is to the Supreme Court and the Constitution as symbols that we must first turn. ${ }^{8}$

Men have always used symbols in the struggle for power, but only latterly have we grown aware generally of their importance. For realistic students of government today know that the state is not ruled, as the unwary reader of Plutarch might suppose, by copy book maxins and civic virtues. ${ }^{9}$ They know that one of the essential techniques of powergroups is to manipulate the most effective symbols in such a way that they become instruments of mass persuasion. The World War with

7. This is the contention of Charles Warren, James M. Beck, Senator Beveridge, Mr. Chief Justice Hughes, and David Lawrence, who have been the principal recent architects of an apologetic for the Court.

8. It is necessary to say that the next two chapters of the book deal respectively with the relation of the Supreme Court to the realities of political power and of the economic system. Together the three chapters form Part I, under the title "The Court in the American Scheme."

9. The power of ideas, symbols and myths, regardless of their validity, to rule men's minds in politics goes back, of course, to the Platonic myths; it reaches through Machiavelli to its modern fruition in Sorel, REFLECTIONS on VIOLENCE (Hulme trans. 1914), from which writer it was presumably derived by Mussolini. It is noteworthy that Sorel, as well as Pareto, was an assiduous student of Greek culture; and Mussolini's fcalty to Machiavelii is made explicit in the dictator's introduction to a French translation of THE Prince. I have profited much, in my thinking on the social myth, from discussions with Professor W. Y. Elliott; see his Pragnatic Revolt in Politics (1928). The most systematic treatment of the role of symbols in the making of the civic mind will be found in the series of volumes edited by C. E. Merriam, notably in Merriam's own summary volume, The Making of Citizens (1931), and in Kosok, Modern Germany (1933). See also Harold Lasswell's works, especially World Politics and Personal Insecurity (1935) and Politics: Who Gets What, When, How (1936). 
its use of propaganda brought that lesson home, ${ }^{10}$ and if it was not clear at the end of the war, it has become clear enough through European experience with fascist and communist governments. Men are notably more sensitive to images than to ideas, more responsive to stereotypes than to logic, to the concrete symbol than to the abstraction. Today we all recognize the power of the newest devices such as the radio, the movies, the press, to act as instruments of social cohesion, and to line up an entire nation behind a single set of interests. The established weapon of dictators has become the microphone. 11 But these techniques depend for their effectiveness upon the symbols that they manipulate, and the symbols depend in turn upon the entire range of association that they invoke. The power of these symbols is enormous. Men possess thoughts, but symbols possess men. ${ }^{12}$

Actually the whole of a culture is shot through with symbolism. Man is under the constant necessity, writes Thurman Arnold, of putting on ceremonial robes, and watching himself go by. ${ }^{13}$ There are symbols like the flag and the national anthem that are clearly recognized as such -well-defined abbreviations of the national culture, sometimes called "referential symbols" because they refer directly to the things they symbolize. But the more important symbols, because their working is more obscure, are the "condensation symbols," which Edward Sapir defines as "a condensed form of substitute behavior for direct expression." "4 This is the symbolism to be found in neurotic behavior, in the life of savages, in the heavily charged symbolic atmosphere of religion and politics.

The Supreme Court as symbol goes hand in hand with the Constitution as symbol. Since the Supreme Court is popularly considered as exercising a guardianship over the Constitution, the result has been to invest the judges of the Court with all the panoply of sanctity with which the Constitution has itself been invested. ${ }^{15}$ This has had for American history an importance that can scarcely be orerestinated. Con-

10. Two of the important American books derive from the war experience: Laswert, Propaganda Technigue and the World War (1927) and Liprasasis, Puelic OpINION (1922); it is from Lippmann that I have gotten the concept of the stereotype. It is not surprising that it is especially in periods of social unrest that the attention of social theory should turn to the irrational elements in mass psychology.

11. I take the phrase from Guy Stanton Ford's Introduction to the symposium, Dictatorship IN THE MOdern WORLd (1935).

12. I owe this sentence to Professor Hermann Kantorowicz, now of the University of London.

13. Arnold, Syarbols of Governarent (1935) iii.

14. In his suggestive article on Symbolism (1934) 14 Excrc. Soc. Scie::ces 492, 493. I owe a good deal of my analysis of symbolism to this article, as also to Arnold, the Merriam series, and Veblen, Theory of the Lersure Class (3d cd. 1918).

15. This is discussed at greater length at pp. 1308-10 infro. 
stitutions, like all creations of the human mind and the human will, have an existence in men's imagination and men's emotions quite apart from their actual use in ordering men's affairs. This function has been called "constitutionalism," which Walton Hamilton has defined as "the name given to the trust which men repose in the power of words engrossed on parchment to keep a government in order."16 Edward S. Corwin, in his Harvard Tercentenary paper, ${ }^{17}$ has pointed out that the Constitution has two aspects: it is an instrument and a symbol. As an instrument it must be viewed hardheadedly and used flexibly to promote the people's welfare in the present and future. As a symbol it is part of the mass mind, capable of arousing intense popular hysteria, loacled with a terrible inertia, its face turned toward the past.

\section{Constitution into Fetish}

To understand the fetishism of the Constitution one would require the detachment of an anthropologist. Every tribe needs its totem and its fetish, and the Constitution is ours. Every tribe clings to something which it believes to possess supernatural powers, as an instrument for controlling unknown forces in a hostile universe. This is true of civilized nations as well. Men need always something on which to fix their emotions, whether positively in the form of adoration or deification, or negatively in the form of a tabu. Like every people, the American people have wanted some anchorage, some link with the invariant.

\section{"Change and decay in all around I see, Oh, Thou who changest not, abide with me."}

And the Rock of Ages has been as essential in the politics of America as in its religion. In fact the very habits of mind begotten by an authoritarian Bible and a religion of submission to a higher power have been carried over to an authoritarian Constitution and a philosophy of submission to a "higher law;" and a country like America, in which its

16. Hamilton, Constitutionalism (1931) 4 Excyc. Soc. Sctences 255. Sec also Frientich, Constitctional Governaient and Politics (1937), especially c. 8-10, for a view of constitutionalism that differs from Hamilton's.

17. Corwin, The Constitution as Instrumcnt and as Symbol (1936) 30 AM. PoL. ScI. REv. 1071. Corwin's contrast between the Constitution as symbol and as instrument will, like so many of his analyses, prove fruitful for constitutional theory. I liave only one warning. "Instrument" may be used in two senses: in one it means, as with Corwin, a frame of government adequate to the weight placed upon it; in another sense it may mean a technique for defeating the democratic will. In this second sense the principal instrument has been the power of judicial review. The true antithesis would place on the one side a pragmatic use of the Constitution, whether through liberal interpretation or through constitutional change; on the other side the symbolism of Constitution and Court going hand in hand with the instrument of judicial review. 
early tradition had prohibited a state church, ends by getting a state church after all, although in a secular form.

Someday there will be an historian with insight and imagination enough to write the real religious history of America. It will not be the history of formal churchgoing religion, nor even that of the sects and the hellfire revivalists. It will be on the one hand the worship of the dynamo and the gods of business enterprise; it will be on the other hand the worship of the Constitution and the Supreme Court. For in the first pair Americans have made concrete the deepest strivings of their nature and era - the quest of what William James called "the bitchgoddess Success." In the second pair they have made concrete their own hopes and fears for their social order.

If we wish to understand with some sense of immediacy the early American hopes and fears we have only to look at the Sovicts today. Travellers returning from Russia agree that the Russian people are filled with a sense of the revolutionary role they have played and the greatness of their destiny. We get from contemporary records a similar sense of America in its days of early statehood. Even as late as 1831, young Alexis de Tocqueville, travelling through the new . Imerica and contrasting it with the Europe he had just left, was impressed by one thing: the feeling that Americans had of being the carriers of a new philosophy of democracy and equality, the sense they had of their peculiar mission in world history. ${ }^{18}$

Actually, of course, all peoples have one time had this sense of uniqueness and mission, although in the older cultures it tends to wear off and a revolution of some sort or other is needed to renew it. Robert Michels has spoken of the two basic myths of patriotism - the myth of unique national origin (der Mythus der Woher) and the myth of unique national destiny (der Mythus der Wohin). ${ }^{10}$ In America the two converged in the myth of a democratic revolution and a revolutionary democracy. Americans took great pride in their revolution. although it must be noted that the pride increased in retrospect as the revolution receded, the revolutionary energy ebbed and the democratic élan grew too dangerous for the men of substance.

The rhetoric of national unity marked the beginning of Constitution worship. $^{20}$ The people rejoiced that the disunity of the Confederation

18. De Tocnueville. Dexocracy in the Umited States (Reeve trans. 1878).

19. Mífheis, Der Patriotisaius (1929).

20. For much of the material in this section dealing with the first deeade of the Constitution I am deeply indebted to Schechter's pathbrealing article, The Early History of the Tradition of the Constitution (1915) 9 Asr. Por. Scr. Rev. 707. I have borrowed from him not only several of the quotations, but much of the perspective. I fear he errs, however, in attributing too happy a set of consequences to the tradition of the Constitution; if it exercised a cohesive force, it lent itself also to the uses of ruling minority groups. 
had been turned into the unity of the Constitution. To be sure, only about five per cent of the country voted on ratification. But there seems little doubt that most of the rest, for all their suspicions that their liberties might be taken away from them, were not averse to the change. A correspondent wrote to Rufus King in 1787 :

"Our people expect so much happiness from the doings of the Convention that they stand ready to adopt anything which may be offered." 21

Partly the spontaneous result of this expectancy, partly planned and prompted by the Federalist supporters of ratification, processions were held in 1788 in Philadelphia, Boston, New York, Baltimore, Charleston and New Haven to celebrate the ratification. In them mechanics marched side by side with noteholders and merchants. An opponent called the Boston procession "a great fulsome parade;" it "may serve to please children, but freemen will not be so easily gulled out of their liberties." That the children were pleased was more important than the gentleman knew. The procession, wrote a Philadelphian to a friend in another city,

"has made such an impression on the minds of our young people that 'federal' and 'union' have now become part of the household words of every family in the city." 22

It was on these "young people" that the success of the new government depended; and when "union" became a household word half the task was done.

What with real enthusiasm and drummed-up eloquence, the myth of a perfect Constitution got off to a fine start. William Maclay, whose acid words in his journal ate away many of the contemporary pretensions but none the less recorded them, wrote in 1791:

"It has been usual with declamatory gentlemen, in their praises of the present Government, . . . to paint the state of the country under the old Congress as if neither wood grew nor water ran in America before the happy adoption of the new Constitution." 23

What eased the path of Constitution-worship further was the fact that the new government was ratified on the ascending arc of a period of prosperity. It was thus possible to attribute to the government not

21. 1 King, Life and Correspondence of Rufus King (1894) 259; quoted in Schechter, sttpra note 20 , at 717 .

22. Hopkinson, An Accotist of the Grand Federal Procession (2d ed. 1788) appendix; quoted in Schechter, supra note 20 , at 718.

23. Journal of Wilitan Maclay (1929 ed.) 399; quoted in Schechter, sitpra note 20 , at 720 . 
only those effects which genuinely flowed from the stopping of the trade wars and the increased sense of confidence among the mercantile groups, but those also which, because of a war-locked Europe, were for a quarter century to play economically into the hands of Anerica. ${ }^{2 t}$ On the crest of this wave of prosperity the exultation over the new America was converted into the tradition of a perfect Constitution. Undoubtedly the sponsors of the new government were happy to have the decision about their work transferred from the plane of debate over principles to the plane of emotion and faith.

There were some, like James Madison in his famous tenth essay of the $F$ ederalist, who saw that faction founded upon disparate property interests lay at the core of all government; but that meant merely that they and others were grateful for the emergence of a rhetoric of the national interest to push class interests into the bacliground. ${ }^{23}$ How Constitution-worship could be used thus was illustrated in the early jockeyings of the Federalists and anti-Federalists for positions of advantage. At first the anti-Federalists opposed ratification. But when it became clear that the new government was popular, the Jeffersonian party accepted its defeat and sought even to train the enemies' guns back on them. In doing this the Jeffersonians had the precedent of a skilful manoeuver by which, in 1787 and 1788, the nationalists under the leadership of Hamilton had appropriated the name "Federalists" with all the emotional associations of decentralization and states'-rights that went with it. It was a daring stroke, "this clearly conscious philological ambuscade into which the American masses fell." ferson was no less daring and in the long run more effective when he and his party abandoned their opposition to the Constitution and became the eager rivals of the Federalists in worshipping it. Both parties showed an amazing unanimity in pointing out the perfections of the Constitution; they delighted in honoring it, and they measured their distance from each other by reciprocal charges of violating it and departing from its spirit. Their divergences were those of interpretation.

24. "American agriculture vibrated in its fortunes with every turn in the Europan balance of power." 1 Beard, The Rise of American Civilizatio: (1927) 391.

25. The students of today have accepted too uncritically the epithet "faction" which was always hurled at attempts to build up a party system. The reason that Federalist theorists were so bitter at the idea of faction was that they feared the party system would show where the majority stood: the rise of parties has been thus the principal instrument for making democratic government effective. Parrington 11 Parruscros; Main Currediss in Aarerican Thoccht (1927)] sees this clearly, in his discussion of political theory at the Constitutional convention; so also does Beard, Econousre Onuams of Jefrersonian Democracy (1915) especially c. 1 and 8. On Mradison in this connection see Beard, The Idea of National Ixterest (1934) c. 1.

26. Schechter, supra note 20 , at 714 . 
Thus the Constitution was serving its purpose as an anchorage of government against the storms of party strife. W. H. Crawford of Georgia had ample reason to complain when he said in 1811 in the House of Representatives:

"It has become so extremely fashionable to eulogize the Constitution, whether the object of the eulogy is the extension or cuntraction of the powers of the government, that whenever its eulogium is pronounced, I feel an involuntary apprehension of mischief." 27

His barb was delightful; but it was this very fact that all parties had become rival worshippers in the cult of the Constitution which proved the greatest stabilizing force in the new government. Always the task of a state has been to find some object of common allegiance which would allow internal quarrels to rage zvithin the fabric of government without destroying it. ${ }^{28}$ A generation like ours, living in a "time of troubles," 20 can understand the value of the symbol of national unity and the fetishism of the Constitution in cementing internal order.

But when we have allowed for the rhetoric of national unity, the persuasion of prosperity, the advantages of having a safety valve to let off the steam of party conflict; when we have added the propaganda of clergymen, lawyers, editors, teachers, we have not completed our analysis. Deeper than any of these were forces operating on the less conscious levels of the popular mind. One was the belief that ordinary people, as well as lawyers, have in word-magic. The American was the first written national Constitution. What matter that it was a broad pathway of government rather than a fixed and narrow code of law? The very definiteness with which the design for a government was set down in

27. Quoted in Corwin, supra note 17 , at 1077.

28. Von Holst, in his chapter on constitution-worship in America [1 VoN HoLst, Constitutional and Political History of the United States (Lalor and Mason trans. 1881) c. 2], quotes Governor Hamilton of South Carolina on "the beauty of our Constitution" at the very moment when Hamilton was nominated as president of the nullification convention in 1832, and Alexander Stephens to the same effect only a month before he became Vice-President of the Confederate States. This "contradiction" fascinated Von Holst and even made hin angry, which is not surprising when we remember that Von Holst was passionately influenced by the German constitutional movement, and wished earnestly to believe in the integrity of constitutionalism. But the serious count in the rhetoric above is not that it was out of line with the bchavior of the two Southerners. It is rather that while in 1832 the rhetoric served its purpose, in 1861 it did not. That purpose was to settle internal clashes without resort to bloodshed.

29. The phrase is from 1 Toynbee, A Study of History (1934) 53. The term "crisis" is best restricted to a specific situation of breakdown in a national culture; thus, an "economic crisis" or a "constitutional crisis." Toynbee used "time of troubles". to apply to the stage of breakdown through which the larger cultures pass, such as the culture of the western world today. 
words on parchment was enough to command admiration and then reverence. $^{30}$ What was wanted was a visible symbol of the things that men hold dear. The American people had conquered a domain from its natives, wrested the sovereignty over it from the greatest power in Europe, fought their way to liberty. They wanted a visible mark of their accomplishment: ecce sigmum. And they wanted it all the more strongly as they began to suspect that in the process of consolidating their regime they had lost sight of their original impulsions and the goals they had dreamt of. What they did, to still their doubts, was what every man does when troubled about his failure to realize his youthful dreams: they sought a way by which their revolutionary ideals could be worshipped without being followed. They found their peace in the safe haven of the Constitution. Here was the document into which the Founding Fathers had poured their wisdom as into a vessel; the Fathers themselves grew ever larger in stature as they receded from view; the era in which they lived and fought became a golden age; in that age there had been a fresh dawn for the world, and its men were giants against the sky; what they had fought for was abstracted from its living context and became a set of "principles," eternally true and universally applicable. ${ }^{31}$ When the Americans began seeing the revolutionary heroes in the hazy light of semi-divinity and began getting them associated or confused with the framers of the Constitution, the work of consolidating the new government was assured. The Golden Age had become a political instrument.

The amazing function that the Constitution as symbol performed was to serve as a link between the revolutionary ferment of the 1770's

30. On word-magic, see Kenneth Burke's suggestive, if somewhat chaotic book, Permanence and Change (1935). There is an item in the article, The Constitution of the Uitited States (July, 1936) 14 Fortune 56, where it is reported that of the thousands who stream through the Library of Congress to gaze at the document in its glass case, many fall to their knees before the magic of the word that holds their national destiny. There are some, of course, who ask to see the signatures of Christopher Columbus and Colonel Lindbergh; but when was ignorance ever held a bar to the appreciation of magic?

31. The process described here is obviously not restricted to American history. It forms the theme also of Carl Becker's brilliant Heavesily Citr of Ine Eigureeniry CENTuRy Philosophers (1932). The appeal to a Golden Age is a common thing in the history of national emotions and political tactics. In fact, Americans vere only carrying on what the English had done in their struggle for Parliamentary libsrties when they had appealed to a Golden Age of primitive Saxonism, with its reliance on the sturdy and deep-rooted habit of meeting in assemblies, as against the Golden Age of the Briton kings, which the Tudor and Stuart apologists sought to emphasize. See Brusi:iey, Arthurian Legend in the Seventeenta Century (1932). I owe much of my thinking in this matter to Edwin Mrims, Jr., of Harvard, and to Borgese's article on Primitivism (1934) 12 ENCYc. Soc. ScIENCEs 398, which is a mine of suggestion. 
and the new nationalist government of the propertied minority.:" On the one hand the prosperity and the sense of order that accompanied the new regime were attributed to the Constitution; by a process of abbreviation, one said "Constitution" when onc meant the new government, thereby assigning to the instrument what was intended for the whole organism. On the other hand, by a process of association, one also said "Constitution" when one meant the ideals for which the revolution had been fought, thereby investing a conservative document with the halo of a revolutionary movement. That the Constitution could serve thus as a link between the Boston Tea Party and Hamilton's Report on Manufactures, between the Declaration of Independence and Dr. Timothy Dwight's speeches as President of lale Lniversity, is a tribute not so much to the document itself or the wisdom of its framers; it is a tribute ultimately to the ironic sequence of events in history, and to men's capacity for fashioning myths that will allow them to adjust themselves to that sequence. ${ }^{33}$ One could. if a dash of cynicism were allowable, lay it down as a political axiom that at least in the early stages of a revolutionary regime a constitution is worshipped in inverse proportion as it embodies the principles for which the revolution was fought. and in direct proportion as it succeeds in creating a framework for order and prosperity.

But the Constitution was no static stmbol. Its fortunes were entrusted to the perilous voyage of the union experiment. There were two powerful thrusts at work in the period before the Civil War - one toward nationalism. the other toward particularism; one emphasizing the needs of survival for the whole, the other clinging to the assertions of freedom for the parts. The quarrel was not one carried on in the void; it mounted in passion and intensity because with it were involved the fortunes of slave-holding and of industrialism. But it is important to note that the fight over these issues of economic interest and state policy

32. The Constitution as it was framed and ratified was, of course, far from a revolutionary document; the new government was a republic rigged up with contrivances for safeguarding the interests of the propertied minority. But the symbolic power of a Constitution was recognized very early by those who had the sharpness to picrce history. Tom Paine, revolutionist as he was, saw from the beginning the power that lay in a "charter" for lashing down the allegiance of the masses to the new regime: "Let a day be solemnly set apart for proclaiming the charter; let it be brought forth placed on the divine law, the word of God; let a crown be placed thereon, by which the world may know that so far we approve monarchy that in America the law is King." Paine, Conmon Sense (1776); quoted in Corwin, supra note 17, at 1074. This was in 1776 , but as a good propagandist Paine was already drawing the blueprints of constitution-worship.

33. Americans of the $1790^{\circ}$ s were able the better to adjust themselves to the contradiction of their position through the figure of George Washington, who spanned the transition from the old fervor to the new order, and who was utilized to the hilt as a symbol. 
had to be waged with constitutional brickbats. That is why the principal figures in the struggle were constitutional lawyers. They were the heroes in a war of words. On the nationalist and industrialist side the great figures were John Marshall on the bench, Daniel Webster and Henry Clay off it, and Joseph Story whether on or off. On the localist-slaveocracy side were Roger Taney on the bench and John C. Calhoun and Thomas Benton off it. And in the wake of these judges and legal scholars came their camp-followers - the nation of amateur constitutional lawyers. ${ }^{34}$ It was in this period. it nust be remembered, in the early 1830's that De Tocqueville came to America and put down his observation that every issue of policy with us was first translated into constitutional terms and debated as a legal issue. ${ }^{35}$

But in the thickest of the battle, the Constitution itself went unquestioned. In fact, the more hotly the diverse interpretations of it were contested, the more unwaveringly did both sides pay homage to it. The climax of the war of words came in 1830, in the debate in the Senate between Webster and Hayne. ${ }^{30}$ There is a sultry magnificence in Webster's Reply to Hayne, which quickens the blond even of the sleptical reader today. ${ }^{37}$ But more important is the fact that this debate was the climax of the attempt to solve national problems through constitutional symbols; and the attempt was a failure.

Webster's speeches represent the high point of the establishment of the Constitutional tradition. Never hefore had men been so aware of the full enotional meaning of national unity. He urased the Constitution as a completed contract between the people themselves - in mediate, fundamental, irrevocable. sacred. But it was not so much his legalistic arguments as the finality and fervor of his statement of them that counted. The notion of a united people superior to the will of the states now emerged. and becane identified with the Constitution. This notion came to its full consciousness on the rising arc of our national life, when the emerging industrialisn was creating in economic terms

34. Corwin's remark is worth quoting: "Many other countries, too-nost of them. in fact-have written constitutions, but 'the constitutional lawyer' is a unique product of our system." Corwin, The Twilught of thr. Surreme Cotmt (1934) xiii.

35. 1 DE TocQueville. op. cit. supra note 18, at 284.

36. This clebate has been insufficiently studied in terms both of its symbolic and of its economic context. I have found the comments of Warren II WARREs. TuE SupReare Cotrt ix United States Histony (2d ed. 1926) c. 1S] and Fuess [1 Dasiel. WeBSTER (1930) c. 15] valuable despite-perhaps because of-my disagreement with their interpretation. Parrington's sketch of Webster [2 PAnBs:ctos, of. cil. supro note 25. at 304-16] is brilliant. So also is Charles Beard's discussion in Tur. Fecovonir Basis of Politics (1934 ed.) 33-40.

37. It is interesting that even the Beards 11 Bram. Tur Risf or Anmicas Civzizatiox (1927) 565], for all their usual tough-mindedness, are moved to a lyric strain by his peroration. 
the organic sense of unity that Webster was trying to use to the purposes of his class and outlook. Webster's speech was therefore a resounding success. It sold as a pamphlet more widely than any other pamphlet since Tom Paine's. It gave balm and re-assurance to a people already troubled by the impending sectional conflict. The enormous impression that Webster's oration made was, however, not due wholly to the "godlike Daniel's" divine eloquence. It must be remembered that this speech, and also the one he made three years later which with the help of the Commentaries of Justice Story was more closely reasoned as a piece of constitutional theory, ${ }^{38}$ were both filled with a sort of inspired Constitution-worship. It was this which stirred the country. That it did so was evidence of the hunger of the people, in the midst of the incertitudes of the slavery debate, to be reassured by some comforting symbol. That symbol was an indivisible union resting upon a sacred charter which was, in Webster's words a "Constitution," not a "Confederacy."

But the hunger for a national symbolism was not enough to solve the problems of sectional and class interests. Von Holst, writing of this period from his vantage-ground after the Civil War, states quite clearly the dual result that attended the use of constitutional debate as an instrument of national policy:

"The Constitution afforded such a field for a war of words . . . that ... the erroneous view began to obtain currency in the third decade of this century that all difficulty would end in a war of tongues . . . the extraordinary dilatibility of the boundaries postponed the moment of the breach." 39

Von Holst was right in both respects. The common clinging to the Constitution while disputes raged over its interpretation - the limitation of the struggle to the arena of constitutional argument - did postpone the moment of the breach. But it was a dangerous method, for it tended to lull men to an oblivion of the bitter realities involved in the struggle. When they placed their complete reliance upon this "war of words," the Civil War became not the irrepressible conflict but the incredible conflict. Hence the necessary economic and political adjustments

38. The 1833 speech, on "The Constitution not a Compact between the Sovereign States" [6 Works (Natl. ed. 1903) 181] is the speech which best expresses Webster's constitutional theory. There is fairly clear evidence that Webster got much of his theory from Story. See 2 Parrington, op. cit. supra note 25, at 311. The Reply to Hayne [6 Works (Natl. ed. 1903) 3] is not his best constitutional argument, but it is the best rhetorical statement, which is much more to our purpose.

39. 1 Von Horst, op. cit. stupra note 28 , at 78 . It was in this period that the fiftieth anniversary of the Constitution was celebrated. For a typical discussion, using the occasion for a bitter indictment of the states'-rights doctrine, see JoHN QunNCY Adams, The Jubitee of the Constitution (1839). 
were not made. ${ }^{40}$ The politicians of the 1830's, like all politicians, finally fell under the sway of their own rhetoric. They actually believed in the efficacy of their legalistic arguments. They trusted in the sanctity of the Union within the symbolism of the Constitution to preserve the Union. The tragedy of Webster's Reply to Hayne was that symbolism did not prove enough.

While the war itself was a tragic defeat for the efficacy of the constitutional symbolism, the northern victory only served to confirm that symbolism. As we shall see in the next section, however, the Constitution itself was no longer asked to bear unaided the burden of solving the problems which threatened the national unity. To the rhetoric of the Constitution was added the divine right of judges and the yeoman's work that the judicial power had to do. The heyday of constitutional symbolism was over with the Civil War. I do not mean there was a slackening of constitutional fetishism. By no means. If anything, that fetishism grew in passion and intensity. But it no longer had to bear the heavy freightage of keeping party disputes in bounds and hemming economic conflicts within the ambit of peaceful political brawls. After the Civil War it is not too much to say that the function of constitutional symbolism became auxiliary to the cult of the judicial power."1

Within these limits the Constitution has functioned as a symbol with great effectiveness since the Civil War, and its very removal from the area of direct conflict has made it more rigid and unyielding as a symbol. As the continent was opened, and a new immigration poured in from Europe, and the population moved toward the Pacific, new sectional, racial and class cleavages emerged. The Constitution was more than ever needed to tie together the loose bundle of faggots, the collocation of races and peoples, the sprawling geographical expanse we call our country. Henry Adams, musing on the Virgin and the dynamo, rifling European capitals for the wisdom stored in their cathedrals and chancellories, took the Constitution for granted, and had perforce to fall back upon inexorable cycles of history in order to find some anchorage in a shifting and turbulent cosmos. Not so the immigrant, first landed

40. The immediate context of the Webster-Hayne debate was the struggle over the land question as related to the slavery question. The Beards [BEARp, loc. cis. suspra note 37] goint out that Webster sought to split the West from the South in their common struggle against northern industrialism, by yielding to the West on the land issue, and by setting up a nationalist ideal to the appeal of which the West was not wholly immune. But by relying too much on the latter, constitutional rhetoric, the Easterners did not push their practical concessions far enough. If they had gone beyond Webster's gesture to the West, "if they had then and there effected a union with the West by yielding on the land question ... they would have made the forces of the Union a combination of power so formidable that secession would bave scarcely dared to face it." 1 id. at $565-66$.

41. This will be elaborated at pp. 1310-12 infra. 
on these shores, who found in the Constitution the certain guarantee of stability that Adams had hunted for throughout Europe. ${ }^{42}$ The Constitution has thus become since the Civil War principally an assimilative and faggot-binding agency, betokening the encompassing tradition into which all sorts of diverse traditions could pour themselves. And tht1s for the children of the new industrial age, native and imnigrant alike, the Constitution became once more what it had been for the generations that succeeded the Revolution - the symbol of a Golden Age. Only the Golden Age, instead of lying in the past, lay in the future. It was located no longer in the lost Atlantis of the Revolution; it was a gateway opening on bright and illimitable vistas of the golden dollar. ${ }^{43}$ As the pecuniary values of a capitalist society supplanted all others, the Constitution was used more and more as a symbol to place a sanction upon those values. It became merged in men's minds with the capitalist myth of the career open to talents in the land of opportunity; the capitalist legend and the constitutional legend blurred into one another until finally their outlines could no longer be distinguished, and they themselves became interchangeable. Which was as it should be in a capitalist democracy.

All this took place by no means spontaneously. The dynamics of building the Constitutional symbol are lost for us among the myriad daily activities of the past. What we do know is that the process of building the Constitutional legend was equal to the task imposed. It became the staple of after-dinner speeches at Bar Association meetings, of occasional addresses by judges, of conventions of patriotic societies, of class-room recitations and nation-wide contests sponsored by newspapers, of talks hefore immigrant groups, of newspaper editorials in the great urban centers and cross-road towns, of radio commentators and movie newsreels. All the media through which popular opinion is created and entrenched were enlisted in its service. Those who are curious will find a revealing cross-section of the constitutional legend in the records that have remained of the centenary celebration of the ratification of the Constitution. held in Philadelphia in 1889.44 But if some of the ex-

42. The part that the immigrants have played in building the effective symbolism of American life has never heen adeçuately explored. It seems clear, however, that their role has been central and at the same time curiously clual. On the one hand, the immigrants have with a naive eagerness tended to swallow whole both the myth of a perfect Constitution and the myth of capitalist success; on the other hand, the "Americanism" which represents the fusion of the two myths has fed largely on native hatred of immigrants.

43. The classic works on the capitalist myth in America are, of course. Thorstein Veblen's, especially Arsextre Owirrship (1923). Of value also is Josephson. The Ronibir Barovs (1934), especially the chapter "What the Young Men Dream."

44. Carson. en.. Histors of the Chiebration of the 100tr Anniversary of the Promudiciation of the Constitution of the United States (1889). It is worth noting that J. Franklin Jameson, writing in 1886. observed that increasing interest in the 
hibits in that record seem to some a bit archaic and baldly naive, let them reflect that in the half-century that has elapsed the process has gone on apace. That our constitutional commentaries have something of the timbre of what the band plays at Fourth of July parades, should not disconcert us. It is of the essence of such works that they should celebrate their fear of change under the guise of a passion for the moral foundations of the Republic. ${ }^{25}$

Latterly constitutionalism has tended to lose its original richness and, as it has increasingly hardened into a fetish, to be turned with increasing naivete to the purposes of reactionary groups. It has, of course, always been true that not all who have made a fetish of the Constitution have believed in it. Samuel Johnson said of patriotism that it was often the last refuge of the scoundrel. This is true of Constitutionalism as well. Many is the newspaper and political group in this country which appeals to the sanctity of the Constitution with its eyes fixed on the inmensities and its hands reaching out for its own special interests. They are the professional patrioteers, and they use the Constitution in a coldly instrumental way for their own purposes. The professional patrioteers may, if we have luck, go the way of other excrescences on the body politic, and be sloughed off in time. But for the present the fetishism of the Constitution on the part of the common man, which has become so deeply part of our tribal ways that it must be taken as a datum in our politics, plays into the hands of all sorts of constitutional "leagues" and Americanism-mongers. It may perhaps be considered evidence of the disintegration of the constitutional symbol that what once served to weld the discordant groups of a nation together has now become the easy label of a whole host of "patriotic" organizations, whose purpose is to stamp out any protest against the existing economic set-up and whose function is to build a popular apologia for the present distribution of power.

\section{Divine Right: American Plan}

In a democracy in the twentieth century it may seem irreverent or whimsical or even merely literary to talk of divine right. Yet very little

Constitution over the last few years had caused the State Department to talie it out of the "little tin box" and place it on exhibition. JAsseson, Ast Iritroduction to tre Study of the Constitutional and Polmtical History of the Umited States (1895) 5.

45. Take, for example, the amazing book by Beck [TnE Cosistituriosi of THE UnITED STATES (1922)] -amazing not in that it differs so much from what 95 per cent of the "constitutional lawyers" of today would write if they wrote books, but in that it was written and published at all as a scholarly commentary. In his review of the book, under the title Constitutional Metaphors (1925) $41 \mathrm{NEw}$ Repunuc 314, Thomas Reed Powell has set down as pitiless a dissection of the anatomy of constitutionalism as exists anywhere. 
is clearer in the American scheme than the fact that the cult of the Supreme Court is the characteristic emotional cement by which American capitalism and American democracy are held together. ${ }^{40}$ The celebration of the Supreme Court in the capitalist America of the nineteenth and twentieth centuries performs the same social function as the celebration of kingship in the mercantilist Europe of the sixteenth to eighteenth centuries. On the main highways of the development of the western world, what used to be the divine right of kings has been replaced by the divine right of judges.

I mean this, of course, as a rough analogy, and yet I mean something beyond that too. The feudal economic system wore the panoply of idea and allegiance furnished by the universal church. The mercantilist economic system that emerged in early modern times clothed itself in the vestments of a kingship that would have the strength to break down and override the princelings and local potentates who stood in the way of the expanding economic unit; but it had to contend with the spiritual authority of the church, and it did not shrink finally from claiming for its kings the same divine right with which the church had invested itself. In fact, as Figgis has pointed out, ${ }^{47}$ the great ideological struggles of the sixteenth century were waged over the claims of the kingship to divine right; and the crux of this struggle is reached when the absolute monarchs in England evolved their dispensing power to set over against the power of the Church to grant indulgences. It seems to be a rule of the struggle for power that one species of appeal to divinity can be displaced only by another. The divine right of the church had to yield to the divine right of kings, which invested the absolute monarchy. That, in turn, in the course of the Parliamentary struggles of the seventeenth century in England and of the eighteenth and nineteenth century struggles that followed in their wake on the Continent, had to give way to the divine right of Parliaments; for representative institutions were able to displace absolute monarchy only by grace of appealing to a "higher law;" the "divinity that doth hedge a king" was transformed into the divine sanctions of some unchanging body of principles in terms of which the king's acts had to be measured and weighed.

But the logic of development did not stop there. America, which has carried capitalism to its highest peak of perfection, needed also a divine sanction of unusual potency with which to invest it. Because our parliamentary institutions - our Congresses and Presidents - are potentially too responsive to democratic impulses, the "higher law" was ex-

46. The nature of the judicial power in our state, how it has grown to its present stature, how it functions in our political and economic system, must be left for later chapters. Here we are concerned only with the strength of the symbolism in the judicial power, and with the psychological ingredients which furnish that strength.

47. Figgis, The Divine Right of Kings (2d ed. 1914). 
tended to hem in the acts of the people's representatives themselves. That "higher law" was located in the Constitution, but being divine it could not be contained even in that. So it overflowed and became a "brooding omnipresence in the sky" 48 which could be brought to earth only when it was finally located in the minds of the men who took over the exclusive function of interpreting the Constitution. As Brooks Adams wrote in 1913, in his masterly Theory of Social Revolutions, by the "rule of reason" in the Standard Oil case of 1911 which exempted the Oil Trust from the operation of the Sherman Anti-Trust Act, ${ }^{13}$ the Court was taking over the authority of the church to "grant indulgences for reasonable causes." 50 From the mediaeval church to American finance-capitalism the wheel has come a full turn. The divine right of judges has supplanted not only the church hierarchy; the feudal aristocracy, the absolute monarchy, but finally even the institutions of parliamentary democracy, and the Constitution itself.

There are three principal elements in the pattern of divine right as it may be found in the popular mind. One is the fetishism of the Constitution, the second is the claim of the Court to the exclusive guardianship of the Constitution, and the third is the tradition of judicial neutrality. I have already dealt with the first in the previous section of this article. To no small extent in the past century the fortunes of the Constitution as symbol and the Supreme Court as symbol have been linked. What enabled the propertied groups, in the last analysis, to make use of the judicial power was the strength and evocative force of the Constitutional tradition.

But this tradition, seen as a cohesive force for the nation, had one great weakness, which I have already sought to suggest. It left the gates wide open for divergent interpretations that, as shown by the quarter-century that furnished a swift runway to Civil War, might grow in passion and intensity until they led to open conflict. The Civil War burned deep into the people the consciousness of the value of the constitutional symbol; it burned even deeper the danger of the conflicting interpretations of the fundamental law. As long as the polity had to cope only with the oppositions of the party system, the constitutional symbol was broad enough to contain those oppositions and give them scope and play. But when the oppositions took on the fierceness of class and sectional conflicts, and when two well-knit economies, each with its emotional loyalties and intellectual rationalizations, met in a head-on collision, it was clear that something more was required than the con-

48. The phrase is, of course, Holmes's, who was more canny in seeing through the judicial symbols than any other incumbent on the Court.

49. Standard Oil Co. v. United States, 221 U. S. 1 (1911).

50. Adarss, The Theory of Soctal Retolutions (1913) 119-31. 
stitutional symbol. That something more was judicial review. Since an open area for endless debate and conflict had been left in a federal framework, based on the separation of powers and subject to a fundamental law, that open area had to be closed. Some one had to be empowered to decide finally how that fundamental law should be interpreted. The decision might, of course, have been left to Congress, but that would have been unthinkable before the Civil War to the slavery interest and localist sentiment; it was unthinkable after the Civil War to the capitalist interest, which above all else feared democracy. Something else had to be found. The fetishism of the Constitution, as a flexible instrument open to various construction, was in itself inadequate. In short, a faith was not enough. It had to be a faith deposited in a pozver. That power was the judicial power. The function of interpreting the Constitution had to be specialized in a single tribunal.

Thus arose the second element in the pattern of divine right: the exclusive claim of the Supreme Court to a guardianship of the Constitution. John Marshall and Joseph Story urged it very early in our history, primarily from the standpoint of safeguarding the Federalist interests. Webster's Reply to Hayne is principally important as a defense, not so much of the Constitution, as of the judicial power. It is significant, as Charles Warren has pointed out, ${ }^{51}$ that it came at the end of the first fierce attack on the judicial power since Jefferson's. Webster saw the judicial power as adding a new bulwark for the propertied interests to the bulwark of the Constitution ${ }^{52}$ - which could be used quite as much by Calhoun and Benton to their purposes as by Clay and himself to their own. What Webster did not foresee was that even the judicial power could be used by the enemy - if they captured the Court. It was one of the ironic twists of history that the arrow which Webster aimed at Hayne and the slaveocracy he stood for was picked up by Taney, another champion of the slaveocracy, and aimed back at Webster and the capitalism of the North. The Dred Scott decision was the logical fulfillment of the Reply to Hayne.

From Marshall through Taney, and increasingly after the Civil War, the Supreme Court offered to guard exclusively the charter of fundamental liberties. They offered to play the role of the Platonic guardians that watched over the mythical Greek republic; they were ready to furnish at once wisdom and militancy. Part of John Marshall's genius lay in his skill in pushing into the background the power that the court was gaining over economic policy, and thrusting into the foreground its role of

51. WARREN, loc. cit. supra note 36.

52. In the long Congressional debate that followed Webster's speech, the issue of the judicial power was thrashed out at greater length than at any time since the Great Judiciary Debate of 1802. In it one may find a full exposition of the claim of the Court to the exclusive guardianship of the Constitution. 
guardianship. This the later judges have encouraged by their continued utterances, and it has become the official theory of the court's power. To be sure, the fact that the role of gurarding the Constitution involved also the power of deciding what the Constitution was, did not by a whit diminish the ardor of the Court in offering its services. Like a jealous Cyclops, it was willing to rule the domain that it guarded.

By the stress laid on this guardianship, the judges have been associated in our minds with the function of protection rather than with the struggle for power. This has been of enormous importance. It has conscripted to the service of the judicial symbol all the accumulated AngloSaxon tradition of the "rule of law." America carried it over from England. But this tradition was in a vague way and under the form of "natural law" itself a carry-over from the Middle Ages. It had become domesticated in England - first, in the subjection of King John to the Magna Charta of the barons at Runnymede; later, by the rising English middle class, acting through Edward Coke, the tough and sturdy Lord Chief Justice stubbornly fighting royal prerogative in the cause of Parliamentary liberties, and writing a magnificent commentary on Magna Charta which was more influential than was the instrument itself in building up the conception of the rule of law. This idea - of the subjection of all public officials to a higher law that is "common" not only in the sense that it is available to all men but also in the sense that it exempts none - was carried over into the American colonies, and took the form here of the conception of the Constitution as a "fundamental law." ${ }^{54}$ It cropped up timorously in some of the early cases that are now cited as forerunners of Marbury $\%$. Madison, 53 and in that case took its first long step toward being converted into the doctrine of judicial review. It has been the principal ideological force bolstering judicial review, as a necessary doctrine in "a government of laws and not of men." It is an influence that lingers today in the minds of those who

53. I have found Dean Pound's article [Rule of Law (1934) 13 Excrc. Soc. Scre:ices 463] illuminating. I have not spoken in the text of one of our links to English legal development-the fact that there is a basic character which the possession of a "common law" gives to a people. The emphasis on this by such writers as Pound is expressed in phrases like "the spirit of the common law," "the genius of the common law." The latest commentator to stress this is, significantly enough, a student whose thinking was formed under the influence of continental juristic thought-Max: Ascoli. See his Intelligence in Politics (1936), especially the suggestive section on American legal institutions and the national character, at 120-42. I am willing enough to accept such an approach, provided one is aware of the danger of slipping into the Geistmongering of the Savigny school; provided also one adds that a common law not only helps create the national character, but is itself hammered out along with other institutions by the driving set of forces in the history of the culture.

54. For a useful summary and analysis of the "higher law" theories, see Hurmes, The Revival of Natural Law Concepts (1930).

55. 1 Cranch 137 (1803). 
have never heard of Coke, and who do not know the meaning - much less the "spirit"- of the common law.

From Coke, to Marshall, Story and Chancellor Kent, to Cooley on Constitutional Limitations, to the New Deal cases is a series of legal steps, but the continuity in them is the appcal to a higher law in the interests of the mercantile and industrial class. There is one paradox worth noting: in England, Coke's doctrine has been maintained only so far as it called for a legal check upon the monarch, but not so far as it applied to a legal check upon the Parliament; in America the check was placed both on the executive and legislature. From having such a check it was only a step to identify it with the Constitution, and from that point only another step to identify it with the guardians and interpreters of the Constitution, and thus to establish judicial supremacy. The paradox, however, resolves itself when ideas are referred back to the interests they serve. It was no accident that the idea of the rule of law was among the reigning forces at our nativity as a nation. It is historically, as well as psychologically, linked with the development and power of the middle class in the western world. It is part of the body of liberal doctrine that the middle class forged in the centuries during which it was clearing its way to power, and that the same class used as a rationalization and as an instrument for achieving power. ${ }^{\text {to }} \mathrm{Just}$ as it was useful originally to the rising capitalist class in removing the obstruction of monarchical and aristocratic interference, so it is useful now to the entrenched capitalist class in fighting off the threat of democratic and labor groups.

Its emphasis has changed, but it has kept its function and its psychological appeal. It has found favorable soil in America, where there has always been a dominant legalistic strain and an elaborate respect for the legal fabric of things. And it has been cherished most by the liberal tradition in American life, which has done little to orient itself to the new demands made upon it by changing industrialism, and which is still fighting all over again the battles of the Stuart period. ${ }^{b 7}$

This brings us to the third element in the pattern of divine right: the tradition of judicial neutrality. The judges could not be proper

56. I borrow here, of course, from LASKI, The Rise of European LiberalisM (1936), which seems to me enormously valuable as an attempt to apply the Marxian methodology to the history of western social thought; see my review, Liberalism's Family Tree (1936) 143 Nation 396; see also for a different view, Coker, Book Review (1937) 46 Yale L. J. 1096.

57. "Against an unplanned and undirected industrialism, and its imminent hazards to life, liberty, and property, we have no constitutional rights. But thanks to John Locke, -or to the thinkers, statesmen, warriors, business men, and jurists who put the punch in his words, - we have adequate safeguards against the resort by any state to the kind of stuff the Stuart kings used to pull." Hamilton, Property-According to Locke (1932) 41 Y ALE L. J. 864, 880. 
guardians of the Constitution unless they approached it with detachment. We have somehow managed in our minds to place the judges above the battle. Despite every proof to the contrary, we have persisted in attributing to them the objectivity and infallibility that are ultimately attributes only of godhead. The tradition persists that they belong to no economic group or class; that they are not touched by economic interests; that their decisions proceed through some inspired way of arriving at the truth; that they sit in their robes like the haughty gods of Lucretius, high above the plains on which human beings swarm, unaffected by the preferences and prejudices that move common men.

There is a curious cult of judges that has grown up in America. President Taft, in the 1912 campaign, said with a trace of seriousness that he believed that Heaven got its quality from the judicial character. ${ }^{2 s}$ No German bourgeois ever surrendered himself more completely to the commanding dignity of a Geleimrat, no pre-Soviet peasant ever bowed lower to the Czar's tax-collector, than we bow before the judicial symbol. Office-holding is, in a democratic state, at best a paradox: we seek after election day to invest with authority a man whom we have the day before impaled upon our invective as the blackest sort of scoundrel. In this sense, democratic government is a perpetual phoenix-renewal of the vigor and dignity of office that have only just now been consumed in the flames of party passion. Our experience with elected judges with the state courts and with the whole army of lesser judicial stalwarts and mercenaries - has certainly not been such as to add to the stature of the judicial office they hold. For that reason the cult of judges and the belief in their neutrality is all the greater paradox.

It is partly explained by our association of judges with the "rule of law." But even more it springs from a deep need in us for some final authority. We are, in a sense, a barbaric people, only several generations removed from the wilderness psychology. The whole development of American life has been riddled with violence, from the first extermination of the Indians, through the ruthless rifling of a continent, to the use of spies and thugs against labor unions and the mowing down of gangster "mobs" under the fire of sub-machine guns. We live in a jungle of fear of such violence, and our exaggerated lip-service to "law and order" ${ }^{\prime 9}$ and our cult of judges are functions of that fear. Most

58. "I love judges, and I love courts. They are my ideals, that typify on earth what we shall meet hereafter in heaven under a just God." Speech at Poeatello, Idaho. "Al" Smith, who in the days before the New Deal mirrored the mind of the common man as well as anyone in political life, could rage at a Tammany boss or a Wall Street banker-but he had nothing short of awe for Judge Cardozo. It was partly, of course, the reverence that Cardozo inspired in everyone because of his personal qualities, but partly also the spell of the ermine.

59. For the "law and order" myth in America, see Arword, Srasrors of Gorers:MENT (1935) c. 7. 
of us feel economically helpless in the midst of a ruthless exploitative capitalism; we feel alone in a vast impersonal urban civilization. We turn to "the law" as our final protection, and we read into the judges our hopes for some one who will be above the battle.

Most of us associate judges with the settlement of ordinary litigation, where political bias seems to us irrelevant; or with criminal trials, where the judge seems to sit as an avenging and impersonal deity, expressing through his function the sense and conscience of the community. What easier than to transfer this conception to the Supreme Court? Especially since there are four elements that seem to magnify the objectivity of the Supreme Court judges as compared with those of lower courts.

One is that they are in a "supreme" court, and presumably of some higher stature than ordinary mortals. The second is that they are appointed and not elected, and escape thus the gruelling experience of a political campaign. The third is the greatness of the judicial tradition of the Supreme Court: some of our judges have actually been men of enormous ability; the fact that their ability has not been conspicuously in the direction of detachment is not generally known; what comes down to us is the almost Periclean devotion to their public trust shown by men like Marshall, Taney and Holmes. ${ }^{60}$ The fourth factor, and perhaps the most important, is that we transfer our sense of the definitive and timeless character of the Constitution to the judges who expound it. From our image of the Canstitution as the ultimate wisdom in government, it follows that the men versed in its lore must reach their conclusions not by the paths of ordinary men, but by some mysterious and inspired processes. The judges become, thus, not ordinary men, subject to ordinary passions, but "discoverers" of final truth, priests in the service of a godhead.

\section{New Symbols for Old}

The men who fashion America's symbols have, on the whole, wrought well the Supreme Court symbol. They have used every material at the command of minorities of privilege when such minorities seek to protect their threatened dominance. They have controlled the newspapers, dictated the editorials, contrived the slogans, selected the text books, approved the lectures, filled the pulpits, guarded the microphones, spoken with learning and authority through their proper oracles, the lawyers.

60. For a good analysis of this devotion, see Frankfurter, The Commerce Clause UNDER Marshall, TANeY AND Waite (1937), which, although a small book, is crowded with insights into the psychological and historical character of the judicial process on the Supreme Court. There seems to be something about the judicial rolyes that not only hypnotizes the beholder but transforms the wearer; Marshall and Taney are the principal, but not the only, instances of men whose capacities for greatness no one suspected until they faced the crucial tasks of the Court. 
They have, perhaps, benefited most from the ministrations of the lawyers. For the lawyer, by the air of mystery in which he wraps himself, and by the impenetrable jargon he uses, is adept at the creation of symbols. The lawyer, moreover, as the expert technician in the refinements of corporate strategy, becomes the lieutenant of Big Enterprise, its closest adjunct in the whole range of professional groups. Most important of all, the lawyer - even more than the preacher and the professor - being specialized in persuasion and hypnosis, manages finally to persuade himself and induce a sort of self-hypnosis that makes him forever after a servitor of the propertied groups. And he is aided in this functioning by his special type of mentality which, as Jerome Frank has pointed out, ${ }^{61}$ has its essence in the clinging to the symbols of authority.

The symbol-makers have, I repeat, wrought well. But recently two sets of forces have been at work undermining the fabric they have been at pains to build. One set has operated through our economic institutions themselves and through the cross-purposes inherent in them. The other has operated through the nature of the judicial process itself.

One consequence of industrialism is that it creates a climate in which a symbol has to be hardy to survive. There is an erosive power in the machine-process which makes men think increasingly in matter-of-fact terms and before which legends tend to crumble away. Thorstein Veblen has pointed out that the technicians and operatives of machines, who spend their days in making, weighing, counting, measuring tangible things, are apt finally to be skeptical of intangible - or what he called "honorific" - values. ${ }^{62}$ But even more important is the instability of capitalism as a system of economic order. The successive crises of American capitalism have left their mark on the judicial power. And the history of the Supreme Court is a sequence of crises of the judicial power which have been related to the crises of the economic system. It is no accident that the gravest constitutional crisis should have coincided with the gravest economic crisis in our history, and that the key-figure in both should be the same President. And each crisis of the judicial power, each conflict with the democratic elements, weakens the judicial power and leaves its deposit for the next crisis to build upon.

This brings us to the second set of forces - those operating through the judicial power itself. Historians of the future will probably count it not the least important result of the Great Depression that it made

61. Frank, loc. cit. supra note 48. A good analysis will also be found in Ronnson, LAw AND tHe LAwYers (1935). Every lawyer should read Berle, The Modem Legal Profession (1933) 9 Encyc. Soc. Scrences 340; it treats, without undue tenderness, "the complete commercialization of the American bar."

62. Notably in The Instinct of Workmanship (1914) and Tre Treonx of BusiNESS ENTERPRISE (1904). 
Americans judge-conscious to a degree they had never been before. The setting of this new consciousness is to be sought in the sharp contradiction between economic collapse and the "trained incapacity" to deal with it of a political system hampered by judicial review. The judges were faced by a fateful choice between the freezing of the vested interests and the survival of the capitalist system - and when they chose the latter and turned "liberal," they revealed all too glaringly a very human changeableness. Moreover, although they had to think in legalistic terms, they had also to respond to social pressures, to the political threat of President Roosevelt's court re-organization proposal, to such faits accomplis of the economic process as the success of the steel and automobile organization drives, which left little choice in the Wagner Act decisions. And for judges who were accustomed to talk in absolutes, to act like any deliberative assembly through pressures and majorities, was to forfeit their godhead.

These were the forces at work; the precipitation of these forces was accomplished by the Great Debate of 1937, which turned the eyes of the nation upon the judicial power. Men began to translate what they learned from watching the decisions into terms that had meaning in the debate over the reform of the judicial power. The most lasting result of the conflict between the New Deal and the Supreme Court was educational. There was a vast area in which Americans had been politically untaught - the area of the judicial power. ${ }^{63} \mathrm{~A}$ set of forces converging on the New Deal decisions accustomed them to regard the judges as interested in social policy and capable of changing their minds. The Supreme Court became its own bitterest enemy, and Mr. Justice Roberts an excellent schoolmaster whether he turned his face stonily toward the past, as in his decision in United States $v$. Butler, ${ }^{64}$ or reluctantly toward the future, as in the Jones and Langhlin case. ${ }^{65}$ Either way, Americans learned how the judicial power works.

They were no longer in complete innocence about the functioning of the judicial process. They began to see that judicial decisions are not babies brought by constitutional storks, but are born out of the travail of economic circumstance. They learned that judges are human, ${ }^{\mathrm{c0}}$ and

63. Just as there was a vast area-that of federal regulation-in which they had been economically untaught. It was Mr. Roosevelt's historic function to serve, more or less consciously, as the instrument for both these tasks of national education. Just as under him Americans went a long way to unlearn their myth of individualist capitalism, and to accustom themselves both to federal regulatory action and trade union bargaining, so under him they took the biggest step they had ever taken in unlearning their allegiance to the judicial power.

64. 297 U. S. 1 (1936).

65. National Labor Relations Board v. Jones \& Laughlin Steel Corp., 57 Sup. Ct. 615 (1937).

66. I have incorporated in this passage the argument and some of the phrasing of my editorial, Judges are Human (1937) 144 Nation 451. 
that the judicial power need be no more sacred in our scheme than any other power. They learned, in their own way, that in America the real political sovereignty resides in the odd man on the court. ${ }^{.7}$ But they learned also that the odd man cannot remain an isolated globule of individual desires and convictions, but must respond finally in moments of intense economic and constitutional crisis to the desires and convictions of the people and the facts of the national life. Whatever happens, it is not likely that they will easily forget that experience. If only for a moment, they peered beyond the symbol of the divine right of judges to the realities of the judicial power. They dared look upon the judicial Medusa-head, and lo! they were not turned to stone.

Education such as this comes hard and is hard paid for. It comes with crises, economic and constitutional. Men are not moved to question their most deeply rooted and most skilfully publicized symbols except under enormous pressure and great need. Only then does the erosive power of their reason begin to function, and their myth-making processes turn to the future instead of the past. In the great need of economic crisis, the measures which were taken to relieve and temper that crisis met and were blocked by the judicial power. It was then that the symbol of divine right began to crumble.

"Thou wast not born for death, immortal Bird!

No hungry generations tread thee down."

Thus wrote John Keats, addressing himself to the deathless symbol of the nightingale. But the Supreme Court is no deathless and unwavering symbol. If its evocative power is on the decline, as I believe it is, it is because it has done what no institution can do and remain unimpaired - stood between the hungry generations and the appeasement of their hunger, between Bill Jones and a minimal standard of decency in living.

I have spoken of hunger. There is fear also to consider. ${ }^{\text {cs }}$ And because of that, the fate of the judicial symbol, for all the erosive pro-

67. The theory of judicial decision as resting on the "odd man" owes more, I think, to Thomas Reed Powell than to anyone else in American legal thought. See, e.g., his remarkable articles, Commerce, Pensions and Codes (1935) 49 HARv. L. REv. 1, 193. The theory holds validly enough for a period of extreme constitutional tension such as that of 1935-37; it is less valid over longer periods; and it is always subject to the criticism that it splits up reality unduly into atoms. I have attempted a criticism of this and other atomistic explanations of the judicial process in The Sufreme Court and American Capitalism (1933) 42 YALE L. J. 668, especially at 696-701.

68. The classic philosopher to make fear the psychological basis of State power was Thomas Hobbes. The best modern statement $I$ know is WooLf, FEan Arid PourTICs (1925), probably the only instance in the literature in which a debate on political theory has its setting in a zoo. There is also a discussion in Wallas, ThE Grear SoCIETY (1914) c. 6. I agree with Laski, however, that the motive to obedience in the 
cesses I have described, is far from clear. The ultimate power of the Supreme Court and the Constitution does not come wholly from the driving force of the vested interests, with all their external control over the moulding of opinion. It comes from what is, in the last analysis, the strongest support any institution or tradition can have - namely, fear. I do not mean fear of the Court, fear of the judicial power, the fear one has of the whip-lash of tyrants. I mean the fear of not having Court and Constitution to fall back upon. I mean the terrible fear of change and the unknown, which is to so many people more powerful even than the felt needs and pressures of the day. For it is fear and not will that underlies a good part of our politics - the creeping fear of people who do not want to make decisions, and prefer to surrender their decisions to others.

This sort of womb-retreat is no unknown thing to social psychology. It is a phenomenon common in every period of reaction, and familiar enough in fascism. ${ }^{69}$ It riddles the middle-class mind especially - the minds of those who have lost their secure economic roots in capitalism and have not yet found roots in the emerging collectivisms. ${ }^{70} \mathrm{We}$ in America are just beginning now really to explore and understand the length and breadth and depth of the middle-class mentality in our politics - fear-ridden, standardized, negativist in its outlook, tenacious of symbols. For that mentality the Court's ancient sureness seems something not to be abandoned, lest we confront an uncharted future.

The propertied groups are not immune to fear either. Their attitude toward constitutional law has in the past been on the whole coldly instrumental. "Every dominant class, as it has arisen," says Brooks Adams, "has done its best to use the machinery of justice for its own benefit." "71

State is by no means solely fear. "It may be doubted whether, save in times of passionate crisis, the vast majority of people ever think of fear in the contest of obedience to the law." Laski, The State in Theory and Practice (1935) 17. I have in mind not the (conscious) fear of State power, but the (largely unconscious) fear of the absence of State power.

69. See, e.g., Schuman, The Nazi Dictatorship (1935); Lassweld, World Politics ANd Personal Insecurity (1935).

70. I owe much in my conception of the place of the middle class today to CoREY, The Crisis of the Midde Class (1935). I have not taken account of Corey's valid distinction between the functional and non-functional middle-class groups; that distinction seems to me to have relevance on the objective plane, but not-for the present at least-on the psychological.

71. Adams, The Theory of Social Revolutions (1913), quoted in 3 Parrington, op. cit. supra note 25, at 232. It is interesting that Mr. Justice Holmes, who came from much the same aristocratic social environment as Brooks Adams, should have arrived at results not very different from his, although by a different route. "This tacit assumption of the solidarity of the interests of society is very common, but seems to us false. . . . But in the last resort a man rightly prefers his own interest to that of his neighbors. . . The more powerful interests must be more or less reflected in legisla- 
The capitalists, as a dominant but minority group operating under democratic procedures, have used the Supreme Court so long and so blindly for their own purposes that they have finally succeeded in undermining its strength and prestige. The spectacle of a presumably national symbol being twisted and turned to class interest has finally broken through even the barrage of rationalization. The capitalists find themselves thus faced with the prospect of losing their principal protection against the tyranny of the majority. And this they can ill afford to do. It is, says Nietzsche in one of his scorching passages, ${ }^{72}$ a sign of the weakening of our ruling aristocracies that they hide behind constitutions, higher laws, humanitarian and judicial symbols; and much the same thought will be found in Pareto and his picture of the élites which do not have the stamina to defend themselves by force and so give way to new élites. ${ }^{73}$ The American capitalist élite is caught in a cruel dilemma. As a non-military ruling class it must depend for its protection upon the courts and the fabric of legality which it can control; as a group specialized to pecuniary values and bent upon maximizing profits and minimizing costs, it must twist the courts to its own purposes, defy laws openly when they are aimed at wresting a share of the national income from them, and thus break the very fabric of legality upon which they depend. ${ }^{74}$ Small

tion; which, like every other device of man or beast, must tend in the long run to aid the survival of the fittest. The objection to class legislation is not that it favors a class, but either that it fails to benefit the legislators, or that it is dangerous to them because a competing class has gained in power, or that it transcends the limits of selfpreference which are imposed by sympathy." The Gos Stohers' Sirilk (1873) 7 Ass. L. Rev. 582, 583; reprinted in Seriver, Justice Oliver Wendeul Holsses: Hrs Bcok Notices and Uncollected LetTers and PApers (1936) 104, 107-03. Holmes' view at that time was thus a curious approach to the Marsian concept, but arrived at through social Darwinism. Where Adams was far more realistic, was in seeing that the dominant class ruled not by capturing the legislatio' machinery, as Holmes thought, but the entire machizery of justice-that is, the judicial system. Actually the legislative machinery, in a democracy like America, is more apt to be captured not by the dominant economic minority but by the non-propertied majority. But Holmes vrote the above in 1873, before judicial review as we know it had begun to be fully developed. Adams wrote forty years later, when it had reached its climax. What is most badly needed today in American jurisprudence is a revaluation of the approach to law and legal history through economic interests. Dean Pound's chapter on "The Economic Interpretation" in his INTERPREtations of Legal History (1923) 92, does scant justice to Pound's usual insights.

72. Nietzsche speaks in Beyond Good AND Evil (4th ed. Zimmern trans. 1923) 109110 , of "the moral hypocrisy of the commanding class" which "knows no other way of protecting themselves from their bad conscience than by playing the role of executors of older and higher orders, of predecessors, of the constitution, of justice, of the law, of God himself."

73. PareTo, op. cit. supra note 4. See my Pareto's Republic (1935) 83 NEw REPUBLTC 135.

74. I have taken the kernel of the argument contained in this sentence from ADarss, The Theory of Soctal Revolutions (1913) and Veblen, The Vested Iiterests aisd the Common Man (1920). 
wonder, then, that they are of a divided mind today; that the crumbling of the judicial symbol fills them with fear; that they do not contemplate with equanimity the prospects either of the gradual surrender of their economic power or of the adventure of fascism. ${ }^{75}$

Their fears, and the fears of the lower-middle-class, have as usual been communicated to the intellectuals - even to those liberated "liberals" who pride themselves on seeing through symbols. They, too, fear the breaking of the fabric of legality - a break which might result either in a revolutionary thrust from below or a fascism imposed from above. We live, they feel, in a complicated and fragile civilization, where it is conceivable that a violent wrench might send the whole structure toppling. What separates us from anarchy is principally the accumulated crust of convention, otherwise known as "law." Like the Britisher in the jungle who clings desperately to the amenities of London life, they are jealous of any infraction of law, especially of property law and constitutional law, which form the fabric of the capitalist order. If they yield an inch, they surrender all. They too are caught in a cruel dilemma. For intellectual groups have learned that revolutions and coups take place when a deadlock in the capitalist system makes democracy incapable of dealing with the continuing crises of the capitalist system; that democracies remain paralyzed so long as they will the ends but do not will the means; and that the further Constitution and Court move from the realities of the common welfare, the more barren they become as symbols and fetishes - fetishes that could easily become in the end the rallying-points of movements to suppress liberal democracy, impose fascism, and stamp out the intellectual groups. Thus they too are divided: at once fearful of the crumbling of the American pattern of divine right, and yet disturbed at the way it functions.

With the lower-income groups the case is somewhat different. Their role - the role of the common man in every culture - has always been at once symbol-breaking and symbol-making. For the common man in the past the Constitution has been a symbol of hope and authority, and the judicial symbol one of protection. He has become the carrier of those symbols; to appease him and lash down his allegiance to the existing order have been their functions. With insecurity and hunger, he has turned increasingly to the symbols of his more direct representatives to legislative remedies, to executive action - above all, to trade union organization. From the California lettuce-picker to the Pennsylvania steel-worker, from the Minnesota truck-driver to the Arkansas tenantfarmer, he has begun to scrutinize afresh the myths that stand between

75. Brooks Adams' comment in 1895 seems relevant today: "The only question which preoccupies the ruling class is whether it is cheaper to coerce or bribe." ADAMs, The Law of Civilization ann Decay (1st ed. 1895) 292. 
him and the satisfaction of his needs. Like the middle-class clerk, storekeeper, white-collar worker, farmer, intellectual, he is insecure and fearful, and insecurity is a breeding-ground for myths and symbols. But he differs from them in one important respect: the path he is treading in his quest for security in the economic system is the path that leads necessarily through new forms of social construction and therefore throngh the creation of new myths.

Thus the common man is again assuming his historic function of symbol-breaker and symbol-maker. Trade-union action, mass political action based upon common mass interests - these represent new collectivities. They are capable of building new myths and are on the way to doing so. But like the Constitutional myth in our early years, they promise to be myths emotionally rooted not in fear but in hope, not in negativism but in affirmation, not in clinging to the old but in a collective will to build the new; and economically rooted not in the class power of a minority group but in an expanding economy for the majority groups. If these groups succeed in their efforts to make tut of the Constitution once more, in Corwin's phrase, an "instrument" for the common interest, the Constitutional symbol will get renewed strength; but the path toward such a reshaping of the Constitutional symbol lies necessarily through the decline and fall of the symbol of the divine right of judges.

These are the forces at work. What pattern they will fall into one cannot prophesy. One can, however, see in what is going on now in the American mind the ultimate struggle that is at the core of every human society - the thrust of hunger against the thrust of fear: fear, clinging to the old symbols, and looking toward the past; hunger, looking toward new economic constructions, reshaping old symbols, shaping new. 